\title{
Article
}

\section{Museums for science education: can we make the difference? The case of the EST}

\author{
Maria Xanthoudaki, Brunella Tirelli, Patrizia Cerutti and Sara Calcagnini
}

This paper addresses the role of museums in education in science and technology through the discussion of a specific project entitled EST "Educate in Science and Technology". The Project puts together methodologies and activities through which museums can be used as resources for long-term project work. In-service training for teachers, work in class with learning kits or with materials brought in by a Science Van, and visits to the museum are planned and developed jointly by museum experts and teachers. The Project proposes a teaching and learning model which sees the museum experience as central and integral part of a teaching and learning process with more effective outcomes. The analysis of the Project activities and methodologies is based on the work carried out at the National Museum of Science and Technology Leonardo da Vinci, which perceives the learner (the visitor) at the heart of its educational methodologies and provision.

\section{Introduction}

The Lisbon agenda, the latest PISA results, young people's disaffection towards science and technology are subjects of the current debate ${ }^{1}$ as well as the origin of specific policy objectives ${ }^{2}$ at national and international level. Science museums and science centres are by now recognized as both fundamental actors in this debate and the institutions for developing awareness, knowledge and critical participation of citizens in dialogue on science and technology. ${ }^{3}$

This is the context in which the 'Educate in Science and Technology' (EST) Project was born. It stemmed from the "need to face the general indifference of young people toward scientific and technological studies in the Lombardia region". ${ }^{4}$ EST is a long-term project funded by the Cariplo Foundation, whose partners are the National Museum of Science and Technology Leonardo da Vinci, the City Museum of Natural History, the Regional Office for Schools and Regione Lombardia (the regional authority for Lombardia). EST suggests an educational model which sees museums in close collaboration with schools and their use as resources of knowledge and skills in science and technology.

The main purpose of this article is to examine the educational model underlying the Project. In this model the museum adds value to the educational process by creating interactive relationships between the museum visit and classroom activities. The article is based on data from the first pilot phase of the project taking place at the National Museum of Science and Technology Leonardo da Vinci. ${ }^{5}$

\section{Aims and methods of the EST Project}

The main objective of the EST Project is to familiarize students and teachers with science, using resources available in Milan and around the Lombardia region, reinforcing cooperation between museums, schools and other local institutions, and promoting the development of a network of science museums. ${ }^{6}$ The objectives of the project are met through a wide range of activities, resources and methodologies, operating in juxtaposition:

a) development of interactive educational workshops, initially in the two science museums of Milan and then in other science museums of the Region;

b) development of teaching and learning resources and materials for work in class contained in Science Kits and Science Vans; 
c) use of the museum as resource for both teachers and pupils;

d) use of hands-on learning and inquiry as the main methods for education in science and technology;

e) in-service training of three teachers per school, with the aim of reaching 3,000 teachers by the end of the Project;

f) development of a network of schools and science museums, as one of the means to grant continuity and Project sustainability.

The Project takes place in two phases: the first, pilot phase was undertaken in the school year 20042005. The National Museum of Science and Technology Leonardo da Vinci and the City Museum of Natural History worked each with twenty-five schools (seventy-five teachers) in order to test the methodologies, resources and materials suggested by the Project. The aim of the pilot phase was to develop an educational model $^{7}$ to be implemented at wider level during the second phase.

The second phase, which began in 2005 and will last until 2009, extends the number of science museums working in collaboration with teachers from their local community. Since 2005, the majority of museums in the Project have been equipped with educational workshops, Science Kits for work in the classroom and teacher training courses. The idea is that, despite the diversity of collections, dimensions or policy across the Region, a common methodological approach can be adopted aiming to make a difference in school science education. This difference is sought through a series of original elements suggested by EST, which make it both an ambitious and complex project.

First of all, EST emphasizes the importance of inquiry and constructivist learning for improving both teachers' and students' approach to science. The objective is not to provide mere 'recipes' of science activities to replicate, but to build skills and knowledge in teachers and students which can be used more widely both at school and in everyday life. This approach is developed through a strong relationship between teacher and museum educator based on a community of practice.

These objectives are strengthened by the participation in the Project of important institutions, such as the Cariplo Foundation, the Region of Lombardia, the Regional Office for Schools, the two science museums of Milan, calling to action a growing number of local museums to work together on a network basis. This partnership ensures financial and political conditions allowing long-term action and a stronger impact on the wider community. It follows that the Project is not a minor example of innovative practice, but a major structured attempt to establish a method which may well go beyond the context of the Project.

\section{The theoretical context}

\section{The 'traditional' model (three-part unit)}

Theoretical and empirical studies argue that a direct connection between museum visit and classroom work strengthens the contribution of museums in teaching and learning. ${ }^{8}$ The underlying hypothesis is that the educational potential of the museum is enhanced if we consider the visit as one of the elements of a three-part unit, as suggested by Hooper-Greenhill, ${ }^{9}$ consisting of: a) preliminary work in class; b) visit to the museum; c) in-class elaboration of the activity after the visit. Thus, in this model, the visit is placed at the centre of the learning process, following preparatory activities and offering stimuli for the consolidation of the acquired knowledge.

Hooper-Greenhill's model represents a fundamental contribution in the field of museum education. It showed how the visit was not to be seen as a simple school trip, sporadic and casual, but as an important educational tool for both teacher and pupil. In the context of a growing acknowledgment of the role of museums in education, the three-part unit model and the relationship between school and museum have been the object of wide attention. A large body of research has examined the characteristics of the educational approach of each of the three components as well as their potential with regard to the learning and teaching process. Results show how the three-part unit model produces positive learning outcomes when explicit links are established between the content of the museum experience on the one hand, and that of classroom activities and the school curriculum on the other. ${ }^{10}$ The basis for success can be found in this case in perceiving the formal (school) and the informal (museum) educational approach 
as complementary rather than contrasting. ${ }^{11}$ In fact, far from being a reason for potential weaknesses, differences in educational practices represent a strength in the educational process: collaboration between museum and school allows the former to acquire the information necessary to create situations for the active engagement of students during activities (trails, workshops, etc.), and the latter to give teachers useful information for their school work. ${ }^{12}$

Thus, the use of the three-part unit model is an important tool for increasing the value of the museum contribution to education. Yet, it is important to notice how this model does not necessarily imply a direct relationship between teacher and museum, since an education program using the museum could be developed by the teacher alone and simply facilitated by the museum educator as bearer of the museum provision. ${ }^{13}$ It is for this reason that the three-part unit ought to be developed into a model which makes best use of the potentials of both the school educator and the museum educator. This may only occur through forms of direct cooperation in all the phases of the project.

\section{The innovative model (four-part unit)}

The EST model aims at transforming the relationship between school and museum. No longer the interaction between teacher and museum educator is limited to scant communication, since we seek to build a structured and lasting relationship between the two subjects. Towards this end, the visit to the museum is an essential moment of an explicit educational project.

Acknowledging the museum as a place for informal education, as a space for 'doing' science, and as a resource for the teacher, precisely matches the educational offer developed within the EST project. In fact, the distinctive characteristic of this model does not lie so much in the number and quality of educational resources offered to schools, but rather in the fact that such resources and services are conceived and planned for working together within the framework of a specific educational process. ${ }^{14}$

Hooper-Greenhill's model already steps away from the case of the simple, isolated visit, building a sequence of situations which reinforce the museum experience. The EST model moves further, creating stronger relationships, thus strengthening the pupils' experience in the museum, the work in class and the role of the teacher. EST represents a significant evolution with regards to Hooper-Greenhill's traditional three-part unit. In fact, it is based on a structure that could be defined, for reasons of symmetry, as a set of four elements: a) teacher training; b) work in the classroom using museum resources (Science Kits and Science Van); c) museum visit; d) use of the project method, as the teaching and learning framework in which the other activities of the project are integrated.

The difference between the two models does not lie only in the fact that EST proposes additional activities (teacher training, project method), but also in the very nature of the various elements and of their inter-connection. The elements of the EST unit refer to a working methodology rather than to a fixed sequence. In other words, while Hooper-Greenhill seeks an opportunity enhance the museum experience through preparatory and follow-up activities in class, the EST model highlights the importance of project work, planned jointly by the teacher and the museum. In this shared project, activities are organized to suit objectives. Thus, the sequence of the different actions is not predetermined: the visit can be placed at the beginning of the project, as starting point and stimulus of pupils' experience, in the middle, or towards the end of it. The choice is made on the basis of the set objectives and, obviously, the museum hosting potential. ${ }^{15}$

The most significant characteristics of the EST model are discussed in detail in the following paragraphs, that is, the project as teaching and learning tool, the specific role of the museum, outreach and teacher training.

a) The project as educational tool

The working together of museum and school is not just a condition for the realization of the different EST activities; it is rather a methodological approach. Joint work between museum and school experts develops into a partnership during all phases of EST and is enhanced through project work.

In this model, project-based work increases the educational potential of the visit through the development of connections between museum visit and school educational processes. It is perceived as a learning and pedagogical tool incorporating the work carried out at school, the needs of students and teachers, what takes place in the museum and the knowledge to acquire; and takes into 
account intentions, objectives and methods of both teachers and museum educators. ${ }^{16}$ In this approach, the museum is seen not as the location of a one-day excursion, but as one element within the complex system of a teaching and learning process, a system identified by shared goals and common products. ${ }^{17}$

b) The role of the museum and its workshops

One of the most significant objectives of the museum is to contribute to young people's familiarization with science through active, cognitive and affective engagement. The interactive laboratories of the National Museum of Science and Technology Leonardo da Vinci are an example of such provision. In the case of EST, these constitute the main educational tool aiming at hands-on learning and awareness of the scientific research. ${ }^{18}$

In the i.lab, experience is triggered by a phenomenon or an object-symbol, and a question, which are the starting point for a chain of events and/or activities conceptually connected to each another. ${ }^{19}$ Discovery and knowledge construction begins with 'something that happens', that is, a phenomenon which calls for observation, description and inquiry. In this process, no explanation is given before the demonstration of the phenomenon, and information is never taken for granted: each new discovery is built on the personal skills and knowledge of each visitor. ${ }^{20}$ This means that no process is identical to the previous or to the following one. In fact, discovery and explanation of phenomena are guided by the learners and therefore determined by their age, expectations and interests. With this approach, the Museum (see note 5) helps understand how scientific research takes place, i. e. that scientific investigation involves forming of hypothesis, observation, testing, trial and error, control, repetitions. Awareness of scientific method can, moreover, contribute to the development of skills that can become useful in the course of everyday life. In this approach the science museum, far from being just the place for exhibiting a series of objects, is the place where the complexity and polyvalence of science and of scientific processes can be presented, along with the cultural, social and philosophical dimensions in which objects and knowledge were born. ${ }^{21}$

c) Outreach activities

A strongly innovative element in the EST Project is the systematic provision of outreach experimental activities conducted in schools by Museum educators. In our case two types of resources were used: a) the Science Kit, containing selected materials and tools to be used by teachers to build a science lab in the classroom and for developing self-guided activities; $b$ ) the Science Van, which brings Museum educators to the classroom and contains materials for additional experiments. The way these resources are used in the classroom is chosen jointly by the teacher and the museum staff, while the content of the various activities is linked to the content of the museum visit.

Students have therefore the opportunity to engage with, and learn about, science through a wide range of experiences and learning methods, while new knowledge is built on the basis of knowledge acquired in previous phases. ${ }^{22}$

d) Teacher training

Investing in teachers' professional development is the means for increasing their knowledge in science and technology and, consequently, for increasing the quality of students' education. ${ }^{23}$ The choice of teacher-training content and approach was one of the most important concerns when developing the EST Project. As Christopher Day clearly argues, teacher training may not properly be able to promote the necessary range of outcomes essential to continuing high quality professional developments, if it is predominantly limited to information, awareness and provisional outcomes. Professional development needs to provide for motivational, affective and institutional outcomes, and outcomes related to knowledge and skills (as against content) and value congruence. $^{24}$

The approach adopted for the EST training courses favors teacher participation in first-hand experiences and offers the opportunity for encountering and reflecting upon activities. Hands-on and cooperative learning, observation, evaluation of outcomes are some of the methods used, encouraging teachers to learn through personal experience and practice. ${ }^{25}$ Direct and personal 
experimentation of phenomena as well as 'active dialogue' between teachers themselves and between tutor and learner allowed also teachers to understand the notions and skills which the students, in turn, would need to acquire. ${ }^{26}$

In the EST model training does not aim at transferring facts or technical skills; rather, it aims at developing abilities in making decisions, theorizing, thinking, so that teachers can teach themselves as well as their pupils. First-hand experimentation was followed by analysis of tools, of conceptual trail and methodology, helping teachers to conduct similar activities in schools or to plan new ones with similar methods. Teacher training was carried out at three levels:

a) the personal level, where teachers are engaged in the educational process as learners through a set of experiences, knowledge, motivations and personal attitudes. In this phase there is no specific reference to their school practice nor to the behavior and learning of their pupils. This situation helps to build first-hand awareness of the contexts and dynamics of learning and to develop personal research by each teacher;

b) the professional level, where the previous work is 'translated' into an analysis of the educational methodologies and of the strategies for facilitating students' learning;

c) the level of action-research, which sees teachers as researchers, able to observe critically their own work in a perspective of constant improvement. ${ }^{27}$

\section{The EST project at the National Museum of Science and Technology Leonardo da Vinci}

The Museum regards education as one of its fundamental goals since its foundation in 1953. Since then, the Museum evolved from an exhibition-based museum to a gradually growing small nucleus of science centre, to the current institution integrating two equally-strong dimensions, the historical and the interactive. The co-existence of a traditional museum of science and technology and an evolving science centre constitutes the distinctive identity of the Museum, on the basis of which its educational philosophy and methodology were also developed. Our educational programmes for teachers, students, families and other audiences offer the opportunity to encounter 'the real thing' in our exhibitions, to learn about the social and cultural contexts in which objects were born, and to explore scientific phenomena in our active areas by experimenting and finding out links with everyday life. The use of both exhibitions and active areas as learning tools contributes to a richer experience of science and technology, operating at different levels: cognitive, affective, physical.

In this context, the Museum devised and realised three interactive laboratories (i.labs) for the EST Project: a) telecommunications, b) robotics, c) genetics and biotechnologies. The i.lab From Telegraph to Internet puts together an exhibition on telecommunications and interactive exhibits; The Robot Workshop examines learning processes through the creation of artificial creatures that interact independently with the environment; the i.lab From Cell to DNA uses experiments designed to address basic notions of genetics and biotechnologies clearly and accessibly.

Choice of content was based on fields of current social interest. The methodology was based on the Museum's own educational approach (in line with the Project set objectives) which encourages active involvement of visitors in learning processes through the use of objects, hands-on activities, exhibits and experiments. The other activities and resources of the Project (training, Science Kits, Science Van) revolve around the three topics following a similar teaching and learning methodology.

The pilot phase of the Project took place as follows:

a) a teacher training course in the Museum introduced teachers to i.lab contents and educational methodology and helped them develop their own projects;

b) teachers carried out work in the classroom based on their projects and on the Science Kit materials (each teacher was provided with a Science Kit free of charge);

c) the Science Van visited the classes on-site and the Museum educators carried out additional activities with the pupils;

d) each class visited the appropriate i.lab at the Museum. 


\section{The visit to the Museum of Science and Technology}

Science literacy is not the prime aim of the educational work but rather "the laboratory practice as a tool for understanding and learning". ${ }^{28}$ The visit to the Museum constituted one of the important moments, during which the i.labs operated as the place for first-hand and personal experience, a space for building knowledge through exploration of phenomena and processes, through creative experimentation and conceptual trial and error process. Educational activities in the i.labs emphasize the importance of sharing ideas and collectively evaluating what is being done. At the same time, they reinforce the conscience that each participant, using her own abilities and attitudes, can bring a significant contribution to the common work. ${ }^{29}$

The goal is therefore to test and disseminate a science education methodology based more on the development of the ability to inquire and reflect or on developing meta-cognitive abilities, rather than on the knowledge of correct answers. To reach this objective, the methodological approach adopted in the three i.labs places the learner at the centre of the pedagogic process, while the exhibit, the hands-on activities and the Museum educator have the role of facilitators of learning and experience.

The laboratory practice is complemented by the study of the social and cultural dimensions of science and technology. The original object and the museum collections are strongly linked to the i.lab experiences during the visit. History of science notions related to the themes of the i.labs are addressed through direct encounters of original objects, particularly in the case of telecommunications, where historical collection and i.lab share the same space.

In this case, the historical object acts as a 'document' containing and recording different meanings and information. The object plays a significant role since its polysemantic power makes it unique and privileged with properties and qualities with a strong cognitive, affective and psychological impact. ${ }^{30}$ The nature of the object allows us to develop different types of knowledge, at different levels of complexity, and to recall information acquired in the past. ${ }^{31}$

\section{The Science Kit and the Science Van}

Science Kit and Science Van are two significant elements of the Project offering opportunities to study a new teaching and learning methodology. The Science Kit has a double objective: it offers resources not usually available at school; and helps the development of a classroom science lab. The Science Kit does not include disposable materials, but contains objects which stimulate inquiry, construction and testing. This means that the hands-on method, adopted during the visit by science museums, is also used in classroom, a fact allowing students to learn through practice rather than text books.

The Science Van offers the opportunity to work in class with a museum educator. This concept is not new in the science museum panorama. The Mobile Exhibit is a frequently adopted method for communicating science through exhibitions, interactives or other activities, specifically conceived for being transported and used in small rooms or in places outside the museum. ${ }^{32}$

In EST, the Science Van complements the work of the teacher while the presence of a museum educator in class creates a special moment of excitement and participation for the pupils. The Science Van is thus a tool for encouraging a closer and long lasting relation between teachers and museum experts; but it also pursues broader objectives: making knowledge and resources available for schools (particularly for those that have difficulties visiting museums), disseminating an interactive lab methodology and breaking access barriers.

\section{Teacher training}

The educational methodology used in the Museum with students was also adopted with teachers. Teacher training is conceived as a tool for teachers' professional development as well as for enriching the work of the classes and, thus, for attracting a wider number of students towards science. The EST training courses developed along two complementary directions: a) develop the practice of scientific labs in schools; b) make external resources available where internal ones are absent. These two paths aim at developing abilities and strategies so that teachers may become facilitators of the pupils' learning. At the 
same time, the competences developed during the training can be used by teachers in other museum visits and integrated in similar experiences in their curricular programming.

Teachers who participated in the training courses kept on working together through the development of a community of practice. ${ }^{33}$ Training was not seen as a self-standing phase of the project, but was regarded both as a tool and as an objective. The trainer is not the 'director of knowledge,' but the facilitator of a learning process, guiding the collective moments and following the work of the teacher at a distance.

Such an approach requires both straight collaboration and long-term commitment of museum and school. This engagement takes time and resources as well as the ability to integrate the various project activities with the normal programming of both the school and museum. In this sense, the EST model supports teachers with training, joint devising of projects, participation in the community of practice and provision of resources. In this panorama, the role of the museum is essential: it stands as a central element in each of the project phases, combining all the different activities and setting the educational methodology guidelines.

The experience and the abilities built during the course are then transferred to the school. During work in class the teacher receives technical-scientific, methodological, pedagogic and organizational advice from the Museum educators. Guidance takes the shape of action-research, through which potential problems or needs for extensions or changes emerge, activated by a process of self analysis and reflection.

In this particular instance, each teacher has developed, jointly with the Museum staff, an educational project implemented during the year 2004-2005. Each one of the projects focused at a specific topic, developed around one of the i.labs and taking into consideration students' age, curricular program and teaching priorities. ${ }^{34}$ The development of each educational project was shared within the community of practice and questions, additional materials, doubts and ideas were circulated among teachers throughout the entire first phase.

\section{Concluding remarks}

It was the aim of this paper to discuss the educational model underlying the EST Project. The building blocks of this model are: a) teacher training; b) work in the classroom using museum resources; c) museum visit; d) use of the project method as the teaching and learning framework in which the other activities of the project are integrated.

Such high degree of integration of all the elements of the Project is based upon the strict, deep, persistent cooperation between school teacher and museum educator. Teachers contribute the formal education perspective and museums the informal education one into a joint working process where the two institutions learn from each other for the benefit of science education. Experimentation and inquiry are the basis for developing skills and knowledge in science and technology while resources such as Science Kits and Science Van enhance the museum experience and offer substantial support to work in the classroom. The meta-objective is to 'make the difference' in science education by strengthening the role of museums as teaching and learning tools and through long-lasting educational actions.

Outcomes from the implementation of the model in the first phase can be classified in terms of what we learned about teacher needs and what we learned about the role of the museum in the education process. First, as far as teachers are concerned, their demand for continuity of the program emerged as a crucial issue, especially in the context of what the Project sets as an objective, that is, the development of competences and of a method bringing change in the science practice. We had examples of teachers taking further their own projects in the interim period between first and second phase and even beyond the beginning of the latter, so that now they also are invited to join working groups originally designed for second-phase teachers only. This is an innovation to the original project which makes the community of practice stronger and challenges the relationship between museum and school. The more teachers enter into the Project with the years, the more demanding this relationship becomes. Project-based work which sees the museum as the main tool within a long-term teaching and learning practice requires close collaboration, consultation and presence.

The Museum is now widely perceived by teachers as a setting in which expert subject knowledge can be sought, where active learning is at its maximum and where experience can be build - all of which help 
teachers address their own practice for science and technology. Indeed, what can be perceived as changing is the way in which the Museum works with schools: the Museum no longer is a mere setting for sporadic excursions, but is finally perceived as an expert which promotes a methodology and engages learners with knowledge rather than imposing one-way meaning. This new role corresponds to the direction science museums and science centres are taking nowadays, a direction going from science literacy and public understanding of science to personal meaning-making and public engagement with science and research. This is the approach we try to develop in school science education as well. Although there are many distinctive characteristics between formal and informal education, ${ }^{35}$ EST encourages an inquiring relationship with science at school as well as in the museum. This is the character of change in school practice endeavored by the Project, based on its educational model and on long-term work.

On the other hand, EST can certainly be defined as an original, challenging and fascinating project for museum educators as well. Beyond issues of quantitative objectives to be reached or resources produced, this Project offers opportunities for professional development and research. Museum professionals create stronger relations with colleagues, discussing and comparing practice and experience. Not often a single Project allows for such a wide and long-term common action set in an experimentation-oriented, openminded context. Work with schools in class and at the Museum are the subject of systematic monitoring by the Museum working group and become the stimulus for action-research on more general methodological issues. The National Museum of Science and Technology has long experience in informal learning and museum-based science education and a strong methodological approach which favors constructivist and inquiry learning. This methodological approach is applied in all education activities with the different audiences and in projects at national and international level. Such methodology found in EST a fertile ground and was strengthened through the various activities. At the same time, EST offered the opportunity to study the application of such methodology in other activities, such as outreach work (Science Van activities, Science Kits going to the classroom), and to experiment it within long-term collaborative and project-based work with teachers.

The second phase will offer the opportunity to bring these issues further and to follow the implementation of the educational model reflecting critically on its impact. During the school year 20062007, the Museum works with ninety teachers distributed in the three i.labs. By 2009, the number of teachers involved will be five hundred, the number that the Museum alone has to reach in the context of the Project. At the same time - making the whole thing more complex and challenging - the second phase involves other museums, which, in turn, collaborate with schools in their local community. Each of these museums carries out the different activities of the Project independently, yet working in close cooperation with one of the two Milanese museums, which allows for two results: on the one hand, workshops and other resources revolve around the science topics addressed by each museum collection; on the other, the model is subject to further experimenting, especially in terms of integration of the activities of the different actors.

Thus, the two Milanese museums, in their role as 'critical friends', follow the work of the different museums and supply advise based on their own experience in devising, building and implementing activities and resources for the Project. Still, all museums participate in common moments of training and discussion which are shared also with experts from other partner institutions, the sought outcome being the emerging of a wide community of museum educators, to present the work done in each museum, and to reflect on the common elements and on the interpretation of the Project in each context. Initially, the priority of these common moments has been to develop what is required by the Project. The next priority, although not all museums have the same timing of action, is to build a network which can ensure dissemination to schools and sustainability of work after the end of the Project. This network should go beyond the single-community provision to an action across communities and to a stronger collaboration between different museums as well. Consequently, work with schools will initially be with museums within a given community, but can expand to include collaboration between teachers and educators across the whole region.

The coming years will offer the opportunity to verify dimensions and quality of the impact of the Project. We hope that the effort and investment of all actors during these years can offer useful stimuli for enriching science education at wider level and for strengthening the educational role of museums. 


\section{Acknowledgments}

The Authors would like to thank the Cariplo Foundation for the financial support allowing the realization of the Project and the study of innovative educational methodologies and resources. Thanks also go to the teachers and pupils who participated with commitment and enthusiasm in the pilot stage of the Project as well as to the Museum staff which developed interesting contents and carefully thought-out methods. We are also grateful to the other partners of the Project for their collaboration and support.

\section{Notes and references}

${ }^{1}$ OECD, Programme for International Student Assessment (PISA), 2003, retrieved July 2006, available at www.pisa.oecd.org. European Commission, Europe Needs More Scientists: Increasing Human Resources for Science and Technology in Europe, Report of the High Level Group on Human Resources for Science and Technology in Europe, 2004, retrieved July 2006, available at <http://europa.eu.int/comm/research/conferences/2004/sciprof/programme_en.html>.

${ }^{2}$ European Commission, Benchmarking the Promotion of RTD Culture and Public Understanding of Science, Report from the Expert Group, 2002, retrieved July 2006, available at <http://www.cordis.lu/era/benchmarking.htm>.

European Commission, Objective 1.4: Increasing Recruitment to Scientific and Technical Studies, Report of the Working Group D 'Mathematics, Science and Technology', Summary of the outcomes and conclusions, 2003. European Commission, 2004, ibid. OECD, 2003, ibid.

USA National Standards Foundation, National Science Education Standards, 2004, retrieved July 2006, available at <www.nap.edu/readingroom/books/nses/>.

3 D. Chittenden, G. Farmelo and B. V. Lewenstein (eds), Creating Connections: Museums and the Public Understanding of Current Research, Walnut Creek, Altamira Press (2004).

P. Born, Community Collaboration: A New Conversation, Journal of Museum Education 31 (2006) 7.

4 Fondazione Cariplo, Progetto EST Educare alla Scienza e alla Tecnologia, Mimeo, 2003, p. 3.

5 Whenever the choice will not generate an ambiguity, the word 'museum' (lower case) refers to the museum institution in general, whereas the word 'Museum' (upper case) refers to the National Museum of Science and Technology Leonardo da Vinci.

${ }^{6}$ Fondazione Cariplo, 2003, ibid. p. 4.

7 In this case, 'model' is understood not as a rigid set of actions and approaches to be implemented uncritically, but as a paradigm which can be flexibly adopted in the different contexts of science museums that participate in the Project, taking into account the particular needs and priorities of the different subjects. What is important in this case is the methodological approach suggested and the type of relationship developed between museum and school, both of which aim to make a difference to the use of museums as teaching and learning resources, and to promote constructivist learning.

8 E. Hooper-Greenhill, Museum And Gallery Education, Leicester, Leicester University Press, 1991.

M. Xanthoudaki, Museum and Gallery Educational Programs in England and Greece: Their Content, Structure and their Contribution to Art Education in Primary Schools, PhD Thesis, University of Sussex, U.K. (1997).

9 E. Hooper-Greenhill, 1991, ibid.

${ }^{10}$ M. Xanthoudaki, 1997, ibid.

${ }^{11}$ E. Miotto, "Museums and Schools: The Case of the National Museum of Science and Technology Leonardo da Vinci of Milan", in M. Xanthoudaki (ed) A Place to Discover: Teaching Science and Technology with Museums, Milan, Museo Nazionale della Scienza e della Tecnologia Leonardo da Vinci with the support of the European Commission (2002a).

${ }^{12}$ M. Xanthoudaki, "Il Progetto Educativo nel Rapporto fra Museo e Scuola", in M. Sani and A. Trombini (eds) La Qualità Nella Pratica Educativa al Museo, Bologna, Editrice Compositori (2003).

${ }^{13}$ M. Xanthoudaki, 1997, ibid.

${ }^{14}$ H. Hein, The Exploratorium: The Museum As Laboratory, Prentice Hall \& IBD (1990).

${ }^{15}$ During the experimentation with pilot classes, visits at the Museum were placed towards the end of the project work, right after classroom activities with the Science Kits and the Science Van. This choice was imposed by the timing for the development of the museum workshop areas and other resources, but it also allowed us to test the effectiveness of this sequence within the learning process.

${ }_{16}^{16}$ M. Xanthoudaki, 2003, ibid. p. 101.

${ }^{17}$ F. Quartapelle, Progettare Insieme l'Europa: Kit di Valutazione di Progetti Educativi Europei, Milano, IRRE Lombardia and Franco Angeli (1999) p.31.

${ }^{18}$ E. Miotto, 2002a, ibid.

${ }^{19}$ E. Miotto, La Proposta Educativa del Museo Nazionale della Scienza e della Tecnologia Leonardo da Vinci, Mimeo (2002b). E. Miotto, Linee Guida per Struttura e Attività delle Aree di Animazione, Museo Nazionale della Scienza e della Tecnologia Leonardo da Vinci, Mimeo (2002c).

${ }^{20}$ J.H. Falk and L.D. Dierking, Learning From Museums: Visitor Experiences and the Making of Meaning, Maryland, Altamira Press (2000).

${ }^{21}$ K. Arnold, Presenting Science as Product or as Process: Museums and the Making of Science, in S. Pearce (ed) Exploring Science in Museums, London, The Athlone Press (1996).

${ }^{22}$ B. Piscitelli and D. Anderson, Young Children's Perspectives of Museum Settings and Experiences, Museum Management and Curatorship 19 (2001) 269. 
${ }^{23}$ M. Dadds, Continuing Professional Development: Nurturing the Expert Within, British Journal of In-Service Education 23 (1997) 31 .

L. Tickle and M. Xanthoudaki, Primary Teachers and the Hunt for Knowledge, Paper presented at the European Conference on Educational Research, Lubljiana, Slovenia, 17-20 September 1998, available at <http://www.leeds.ac.uk/Educol/Ecer98.htm>.

${ }^{24}$ C. Day, In-Service Teacher Education in Europe: Conditions and Themes for Development in the $21^{\text {st }}$ Century, British Journal of In-Service Education 23 (1997) 39

${ }^{25}$ E. Miotto and M. Xanthoudaki, Progetto EST: La Formazione degli Insegnanti, Museo Nazionale della Scienza e della Tecnologia Leonardo da Vinci. Mimeo (2003) p. 4.

${ }^{26}$ J. Dewey, Le Fonti di Una Scienza dell'Educazione, Firenze, La Nuova Italia, 1929/1967;

J. Bruner, The Process Of Education, Cambridge MA, Harvard University Press (1960).

D. Kolb, Experiential Learning, New Jersey, Prentice Hall (1984)

G.E. Hein, Learning in the Museum, London, Routledge (1998).

${ }^{27}$ L. Tickle and M. Xanthoudaki, 1998, ibid. M. Xanthoudaki, L. Tickle and V. Sekules, Finding art expertise: experiences of primary school teachers, Journal for In-Service Education 25 (1999) 571.

${ }^{28}$ E. Miotto and M. Xanthoudaki, 2003, ibid. p. 5.

${ }^{29}$ E. Miotto and M. Xanthoudaki, 2003, ibid. p. 5.

${ }^{30}$ S. Pearce, Objects as Meaning; or Narrating the Past, S. in Pearce, (ed) Objects Of Knowledge, London, The Athlone Press (1990).

${ }^{31}$ M. Xanthoudaki, La Visita Guidata Nei Musei: da Monologo a Metodologia di Apprendimento, Nuova Museologia 1 (2000) 10.

${ }^{32}$ Mobile exhibits are used, for example, at the Natural History Museum in New York, at the Cité des Sciences et de 1'Industrie in Paris, at the China Association for Science and Technology, at the National Science and Technology Centre in Canberra, at the Science Centre Technopolis in Belgium.

${ }^{33}$ J. Lave and E. Wenger, 'Situated Learning: Legitimate Peripheral Participation', Cambridge, Cambridge University Press, 1991, retrieved July 2006, available at <http://www.infed.org/biblio/communities_of_practice.htm〉.

${ }^{34}$ E. Damiano, Guida alla Didattica per Concetti, Milano, Juvenilia, 1995.

${ }^{35}$ Miotto, 2002a, ibid.

\section{Authors}

Maria Xanthoudaki is Head of Education and of International Relations at the National Museum of Science and Technology Leonardo da Vinci of Milan, Italy. She holds a PhD on Museum Education from the University of Sussex, UK. Before joining the Museum of Science and Technology, she was Senior Research Associate at the Department of Education and Professional Development of the University of East Anglia. Her research focuses on museum education, teacher training and training of museum educators. E-mail: xanthoudaki@museoscienza.it.

Patrizia Cerutti is coordinator of the Unit for Education Programmes of the National Museum of Science and Technology Leonardo da Vinci. She holds a Degree in Fine Arts from the Academy of Brera. Initially she worked for the Unit for Exhibition Development and then became curator of the i.labs on paper making and on light and colour. Her studies on Education led her to work on programmes for schools and other audiences. She is the coordinator of the EST Project. E-mail: cerutti@ museoscienza.it.

Sara Calcagnini works at the Unit for Professional Development and Educational Research of the National Museum of Science and Technology Leonardo da Vinci. She holds a Degree in Cultural Heritage Studies from the University of Pisa. Her work focuses in particular on the development of programmes on Science and Society and on educational research. She represents the Museum at the European project SEDEC "Science education for the development of European Citizenship" in partnership with museums and training institutions from seven countries.

E-mail: calcagnini@museoscienza.it 